Check for updates

Cite this: RSC Adv., 2019, 9, 13336

Received 11th December 2018

Accepted 24th March 2019

DOI: $10.1039 / c 8 r a 10185 j$

rsc.li/rsc-advances

\section{Microwave plasma-assisted silicon nanoparticles: cytotoxic, molecular, and numerical responses against cancer cells}

\author{
Rizwan Wahab, (DD *a Farheen Khan, ${ }^{\text {tb }}$ Anoop Gupta, ${ }^{\mathrm{c}}$ Hartmut Wiggers, ${ }^{\mathrm{c}}$ \\ Quaiser Saquib, ${ }^{a}$ Mohammad Faisal ${ }^{d}$ and Sabiha Mahmood Ansarid
}

\begin{abstract}
Silicon nanoparticles (SiNPs), which have a special place in material science due to their strong luminescent property and wide applicability in various physicochemical arenas, such as solar cells and LEDs, were synthesised by a microwave plasma-assisted process using an argon-silane mixture. Several characterization tools were applied to check the crystallinity (XRD) and morphological (FESEM, TEM, 20 $\pm 2 \mathrm{~nm}$ size) and topographical (AFM, $\sim 20 \mathrm{~nm}$ ) details of the NPs. The high-purity SiNPs were applied on myoblast cancer cells to investigate the reactivity of the NPs at different doses (200, 1000 and $2000 \mathrm{ng}$ $\mathrm{mL}^{-1}$ ) for different incubation periods ( $24 \mathrm{~h}, 48 \mathrm{~h}$ \& $72 \mathrm{~h}$ ). The MTT assay was utilized to determine the percentage of viable and non-viable cells, while the cell organization was observed via microscopy and CLSM. Additionally, the molecular responses (RT-PCR), such as apoptosis, were analyzed in presence of caspase 3 and 7, and the results showed an upregulation with SiNPs. To validate the obtained data, analytical studies were also performed for the SiNPs via statistical analysis and the most reliable data values were evaluated and acceptable as per the $\mathrm{ICH}$ guidelines.
\end{abstract}

\section{Introduction}

High-purity silicon nanoparticles (SiNPs) with a luminescent property are currently a hot topic because of their wide applicability in optoelectronics as they usually exhibit a p-type or stype semiconductor behaviour depending on their structure. ${ }^{1-3}$ Several research studies have been published on porous silicon fabricated by different methods. ${ }^{4}$ For various applications, it's necessary to obtain well characterized nanocrystals of SiNPs as varying the size of nanomaterials can change their fundamental properties and generate various properties such as electronic, optical, magnetic, and catalytic properties, associated with their nanoscale or quantum-scale dimensions. ${ }^{5}$ There is a wide range of applications for silicon and its nanoparticles, many of which are well-established, such as bioimaging, ${ }^{6,7}$ inorganic/organic light emitters, ${ }^{\mathbf{8}, \mathbf{9}}$ solar cells, ${ }^{\mathbf{1 0}, \mathbf{1 1}}$ dye-sensitized solar cells, ${ }^{\mathbf{1 2}}$ lithium-ion batteries, ${ }^{\mathbf{1 3 , 1 4}}$ corrosion shields, ${ }^{\mathbf{1 5}}$ anti-static films and coatings, ${ }^{16}$ energy storage ${ }^{17}$ and catalysts. ${ }^{18}$ To get nanostructures in the form of nanoparticles, various

${ }^{a}$ Zoology Department, College of Science, King Saud University, P. O. Box 2455, Riyadh 11451, Saudi Arabia. E-mail: rwahabo5@gmail.com; Tel: +966-5360-23284

${ }^{b}$ Chemistry Department, Faculty of Science, Taibah University, Yanbu, Saudi Arabia. E-mail: khanfarheenchem@gmail.com; Tel: +966-5716-03069

${ }^{c}$ Institute for Combustion and Gas Dynamics, University of Duisburg-Essen, Duisburg, Germany

${ }^{d}$ Department of Botany \& Microbiology, College of Sciences, King Saud University, P. O Box 2455, Riyadh 11451, Saudi Arabia physicochemical methods have been adopted, such as the chemical solution method, ${ }^{19}$ sol-gel method, ${ }^{20}$ hydrothermal method, ${ }^{21}$ ball milling method, ${ }^{22}$ one-pot synthesis, ${ }^{23}$ electrochemical etching, ${ }^{24}$ hydrogen-terminated solution process, ${ }^{25}$ reverse micelle process ${ }^{26}$ and the micro-emulsion technique. ${ }^{27}$ Although chemical processing methods are cheap and inexpensive, the purity and crystallinity of the material is a subject of concern. In addition to chemical methods, silicon nanoparticles have also been prepared by the high temperature or thermal decomposition methods, ${ }^{28}$ such as laser ablation, ${ }^{29}$ vapor-phase thermal decomposition, ${ }^{\mathbf{3 0}}$ plasma process, ${ }^{31}$ thermal decomposition, ${ }^{32}$ plasma enhanced chemical vapor deposition method (PECVD), ${ }^{33}$ inert gas condensation, ${ }^{34}$ pulse vapor deposition, ${ }^{35}$ laser pyrolysis, ${ }^{36}$ flush spray pyrolysis,${ }^{37}$ and electrospraying. ${ }^{38}$ Herein, the SiNPs were prepared using a microwave plasma reactor. In this reactor, an argon-silane mixture was introduced into the reaction chamber together with hydrogen gas. The silane was decomposed by microwave energy. The adopted process afforded high-quality SiNPs with a good crystalline character. Although silicon is a valuable material in terms of its various applications, only limited information is available in the literature related to its biological applications. ${ }^{39}$ SiNPs have been used as an anti-bacterial agent ${ }^{40}$ as well as in drug and gene delivery, ${ }^{41}$ protein binding, ${ }^{42}$ the detection and adsorption of DNA, ${ }^{43}$ bioimaging, etc. ${ }^{44}$ Recently, they have been utilized to control the proliferation of various types of cancer cells, where various sizes of nanoparticles ranging from $20-200 \mathrm{~nm}$ were employed in a cytotoxicity study 
to check their effects with various parameters, such as doses, size, and cell type against A549, HepG2 epithelial cells, and NIH/3T3 fibroblasts. The $60 \mathrm{~nm}$-sized SiNPs were endocytosed by cells and caused an unequal decrease in cell viability, which led researchers to elucidate that the NPs induced cytotoxicity. ${ }^{45}$ The $20 \mathrm{~nm}$-sized SiNPs expressed cytotoxic effects on gastric cancer cells (MGC80-3) and cervical adeno carcinoma epithelial cells (HeLa), where cells were shown to be more susceptible to the cytotoxic effect induced by SiNPs. ${ }^{46}$ In another report, human skin epithelial (A431) and human lung epithelial (A549) cells were introduced to $15 \mathrm{~nm}$-sized SiNPs to show their effects in terms of cytotoxicity, oxidative stress, and apoptosis at different doses (conc. 25-200 $\mu \mathrm{g} \mathrm{mL}^{-1}$ ) in a dose-dependent manner. ${ }^{47}$ The SiNPs were functionalized with various chemicals, such as amines, neutral azides, or carboxylic acids, and introduced to check their efficiency against caco- 2 cells. The obtained information suggested that the cytotoxicity depended upon the surface area of the introduced materials. ${ }^{48}$ The dextran-coated SiNPs showed a lower cytotoxicity as compared to the uncoated nanoparticles in in vitro experiments. The results indicated a mild effect of ultrasonic irradiation and SiNPs on cancer cells. ${ }^{49}$ In another report, silica nanoparticles were utilized to examine the cytotoxicity of cells in human squamous carcinoma cell line (SCC25) with curcumin (CUR) for their drug delivery and anticancer activity. ${ }^{50}$ Polymer-coated silica nanoparticles (e.g., polyethylene glycol (PEG)) at different molecular weights were utilized against two cell lines, namely, macrophages RAW 264.7 and primary human fibroblasts, and a reduced toxicity of the PEG-coated silica NPs could be observed when compared to those without coated silica NPs. ${ }^{51}$ The results of the study were also confirmed by another group with the same cell lines, i.e., RAW264.7 cells under in vitro conditions, where they tested the cytotoxicity, DNA damage, apoptosis, and cell cycle following treatment with NPs in cells. ${ }^{52}$ In another work, the authors reported that surfactant (cetyltrimethyl ammonium bromide CTAB)-capped silica nanoparticles did not significantly affect the cytotoxicity against cancer cells, as observed at longer periods. The CTAB prevented the hemolytic activity, which causes minimal damage to the tissues and blood constituents. ${ }^{53}$ Using nano- and micro-sized particles, a comparative cytotoxic study was performed with $\mathrm{ZnO}(100 \mathrm{~nm}$ and $5 \mu \mathrm{m})$ and $\mathrm{SiO}_{2}(10-20 \mathrm{~nm}$ and $10 \mu \mathrm{m})$ with two different cell lines, namely human lung epithelial cells (L132) and human monocytes (THP-1). In this study, it was observed that different sized NPs influenced the cytotoxicity, whereas bigger sized particles had no such effect on the cytotoxicity. ${ }^{54}$ In addition to pristine NP, gold-decorated silica mesoporous NPs ( $\mathrm{Au} @ \mathrm{mSiO}_{2} \mathrm{NPs}$ ) were studied against the breast cancer cells (MCF-7) and compared with bare gold particles. The results of the study indicated that the decorated SiNPs exhibited slower toxicity as compared to bare gold NPs. ${ }^{55}$

The aim of the current study was to establish the utilization of highly crystalline silicon nanoparticles (SiNPs) fabricated by a microwave-assisted synthesis using an argon-silane mixture $\left(1 \% \mathrm{SiH}_{4}+99 \% \mathrm{Ar}\right)$ in a reaction chamber under hydrogen atmosphere. The novelty of the present study is to utilized method provides highly crystalline SiNPs, whereas other chemical and physical methods afford only amorphous SiNPs. Furthermore, pure and highly crystalline NPs were also employed to check the cytological potential on myoblast $\mathrm{C} 2 \mathrm{C} 12$ cells, which has not yet been explored for SiNPs under in vitro conditions in a dose-dependent $\left(200,1000\right.$ and $\left.2000 \mathrm{ng} \mathrm{mL} \mathrm{mL}^{-1}\right)$ manner. XRD was performed to distinguish the size, phases, and crystalline properties of the prepared NPs, while the general structural features were elucidated via FESEM and TEM. The surface topography was examined through AFM. The \% of viable and non-viable cells was scrutinized through MTT assay and the structural changes caused by the NPs in the cells were studied via microscopy. The density of cells in liquid medium was also tested via CLSM, whereas the apoptosis in cells with SiNPs and their molecular study were performed with caspases 3 and 7 with GAPDH genes. On the basis of the obtained data, a mechanism is also presented to show the detailed process of apoptosis or cell death via the SiNPs. The statistical calculated data values were validated to assure the nanomaterial quantity using an analytical development method. The utilization of nanomaterial and their effective approach emphasize to system suitability at $95 \%$ confidence level with authorize parameters.

\section{Materials and methods}

\section{Experimental}

Synthesis of silicon nanoparticles (SiNPs) in a microwave plasma reactor. The SiNPs were prepared with the use of a microwave plasma reactor (Institute for Combustion and Gasdynamics). To prepare SiNPs, an argon-silane mixture (1\% $\mathrm{SiH}_{4}+99 \%$ air) was introduced into the reaction chamber together with hydrogen. Microwave energy was used to decompose the silane. The microwave generator was operated at a frequency of $2.45 \mathrm{GHz}$ and a maximum power of $2000 \mathrm{~W}$. Microwave energy was coupled with the gas flow to generate plasma. The pressure in the reaction chamber was maintained at approximately 30 mbar. In this process, upon entering the plasma, the diluted precursor dissociates into silicon and hydrogen. Downstream of the plasma at lower temperatures, the particles grow by Brownian coagulation, coalescence, and surface growth. By varying the microwave power, the pressure in the reaction chamber, and the concentration of the precursor, particles with different sizes can be synthesized, as reported previously. ${ }^{1,2}$ The obtained NP structures were characterized in terms of their physicochemical conditions.

Material characterization. The acquired SiNPs from the microwave-assisted plasma synthesis process were characterized. The morphological characterizations were accomplished via FESEM (S-4700 from Hitachi, Tokyo, Japan) and TEM (JEM JSM 2010 from JEOL at $200 \mathrm{kV}$, Tokyo, Japan). For the analyses, the prepared light brown colored nanopowder was uniformly spewed on carbon tape. To get good quality images and to avoid a charging effect during examination, sputtering was performed for coating the nanopowder with thin osmium tetra oxide $\left(\mathrm{OsO}_{4}\right)$ for $5 \mathrm{~s}$. To analyze the dimensions of the nanostructures, the prepared material was kept in a $100 \mathrm{~mL}$ capacity beaker with ethanol (EtOH) and sonicated for about 10-15 min. To this solution, a carbon-coated copper grid was inserted for 1-2 s and 
dried at room temperature. The TEM images of the prepared NPs were obtained at an acceleration voltage of $200 \mathrm{kV}$. The crystallinity, phases, and size of the NPs were determined by Xray diffractometry (XRD, Rigaku, Tokyo, Japan) with $\mathrm{CuK}_{\alpha}$ radiation $(\lambda=1.54178 \AA)$ and $2 \theta$ ranging from $20^{\circ}$ to $80^{\circ}$ with a scan rotation of $6^{\circ} \mathrm{min}^{-1}$. The chemical functional behaviour of the produced powder was examined via Fourier transform infrared (FTIR PerkinElmer, U.S.A) spectroscopy in the range of 4000-400 $\mathrm{cm}^{-1}$. In addition, the surface topographical morphology of the synthesized Si-NP material was characterized via atomic force microscopy (AFM). For the AFM (Veeco Instruments, USA), a small amount of powder sample was dissolved in acetone $(2 \mathrm{~mL})$ and then deposited on a silicon wafer $\left(2 \times 2 \mathrm{~cm}^{2}\right)$ dropwise $(\sim 10-20 \mu \mathrm{L})$ and dried under a lamp (Philips, $250 \mathrm{~W}$ ) over $30 \mathrm{~min}$. For the dynamic light scattering (DLS) and zeta ( $\zeta$ ) potential, the SiNPs were dissolved in double deionized water (DDW, $5 \mathrm{mg} \mathrm{mL}{ }^{-1}$ ) and further diluted to achieve a concentration of $50 \mu \mathrm{g} \mathrm{mL}{ }^{-1}$. The obtained diluted solution was sonicated in a bath sonicator $(\sim 40 \mathrm{~W})$ for $30 \mathrm{~min}$ for complete separation of the NPs. The hydrodynamic particle size of the prepared SiNPs and the zeta $(\zeta)$ potential in an aqueous suspension were determined by measuring the dynamic light scattering (DLS) using ZetaSizer (Malvern, UK).

Proliferation of cells. The purchased cells (ATCC, USA) were proliferated with a cell culture medium (Dulbecco's modified Eagle's medium, DMEM; Sigma Aldrich Chemical Company, Pvt. Ltd., USA) at $37^{\circ} \mathrm{C}$ in a water bath $(\sim 3 \mathrm{~min})$. The obtained cells were transferred to the centrifuge tube and the cells were centrifuged for $4 \mathrm{~min}$ at $1200 \mathrm{rpm}$. After the centrifugation, the cell supernatant material was removed from the Eppendorf tubes and the cells were transferred to a culture flask. To this, FBS (fetal bovine serum 12-15\%) and antibiotics (10-15 $\mathrm{mL} \mathrm{L}^{-1}$, ATCC) were mixed and the cell proliferation was observed and the cells were counted. The cells were humidified with $5 \% \mathrm{CO}_{2}$ and 95\% air environment. Further, the cells were washed with DPBS (Dulbecco's phosphate buffered saline), with the medium refilled every alternate day. When the cells reached about 50$60 \%$ confluence, they were subcultured again. The plastic consumables related to the culture wares and other equipment used in this study were procured from Nunc (Denmark). ${ }^{\mathbf{5 6 , 5 7}}$

MTT assay (cell viability). The cell viability was assessed using a cell proliferation kit I (MTT, ROCHE, Ltd U.S.A) as per the manufacturer's instructions. In brief, the proliferated cells were seeded into specialized 96-well plates at $5 \times 10^{3}$ cell per well and incubated overnight at $37{ }^{\circ} \mathrm{C}$ with $5 \% \mathrm{CO}_{2}$. After their optimal confluence, the cells were treated with different concentrations of SiNPs and further incubated for 24, 48 and 72 h. The MTT [(3-(4,5-dimethyl thiazol-2-yl)-2,5-diphenyl tetrazolium bromide)] solution $(10 \mu \mathrm{L}$ per well $)$ was mixed with culture/growth medium (Dulbecco's Modified Eagle's Medium (DMEM)). The stored MTT solution was added to the control and treated with SiNPs and again incubated at $37{ }^{\circ} \mathrm{C}$ for $4 \mathrm{~h}$. Thereafter, the samples were removed from the incubator and mixed with solubilizing buffer (DMSO, $100 \mu \mathrm{L}$ per well) solution. A purple colour was visible at this stage and it became faint with pipetting. The control and treated samples were further incubated overnight to ensure that the formazan precipitate was dissolved. The measurement of the MTT assay was performed with Elisa Reader (BioRad) at $570 \mathrm{~nm}$. The UVirradiation was provided by a deuterium and xenon lamp.

Confocal microscopy scanning microscopy (CSLM). For the quantifiable assessment of $\mathrm{C} 2 \mathrm{C} 12$ in presence of SiNPs, the cells were proliferated in a culture disk and when they reached optimum confluence, varied concentrations of NPs were introduced. For this, the cells were incubated at $24 \mathrm{~h}$ at $37{ }^{\circ} \mathrm{C}$ with $5 \% \mathrm{CO}_{2}$. As the incubation upsurged to $\sim 60 \%$ confluence, the disk culture medium was changed and washed with PBS twice. It was then fixed with ethanol $(70 \%)$ to keep the solution for entire fixation. The fixed cells were washed again with PBS and the medium was removed from the disk. Propidium iodide (PI) was used to stain the cells as previously performed, ${ }^{56,57}$ which were then incubated at $37^{\circ} \mathrm{C}$ for $30 \mathrm{~min}$ in an incubator and washed with PBS buffer. The cells were covered with a cover glass and fixed with adhesive.

Total RNA extraction from the cultured cells. The RNA was extracted from the cultured $\mathrm{C} 2 \mathrm{C} 12$ cells with various phases of treatments, such as cell homogenization, phase separation, RNA precipitation (washing and re-dissolving), reverse transcription, synthesis of first strand cDNA from total RNA, and primer designing for real-time PCR, in set periods of time using trizol (sigma) as per the manufacturer's protocol. The purity of the total RNA was assessed by the optical density ratios at wavelengths ranging from $260 \mathrm{~nm}$ to $280 \mathrm{~nm}$ (acceptable between 1.6 and 2.1). First strand cDNA was synthesized from $1 \mu \mathrm{g}$ of the total RNA using M-MLV reverse transcriptase with the anchored oligo $\mathrm{d}(\mathrm{T})_{12-18}$ primer. RT-PCR was performed using a cDNA equivalent of $10 \mathrm{ng}$ of total RNA from each sample with primers specific for caspase 3 and 7 genes with the housekeeping gene GAPDH. The reaction was carried out in a $10 \mu \mathrm{L}$ volume using SsoFast ${ }^{\mathrm{TM}}$ EvaGreen ${ }^{\circledR}$ Supermix(Bio-Rad) as per the manufacturer's instructions. Relative ratios were calculated based on the $2^{-\Delta \Delta C_{\mathrm{T}}}$ method. PCR was monitored using the CFX96 ${ }^{\mathrm{TM}}$ Real-Time PCR detection system (Bio-Rad). ${ }^{56-59}$

Statistical analysis. Statistical analysis was performed to authenticate the Student $T$-test, mean \pm SD and standard pool at a significant value $(P<0.05)$.

Analytical determination. Analytical determination of the nanomaterial concentration of SiNPs $\left(1 \mu \mathrm{g} \mathrm{mL}{ }^{-1}\right)$ and their hostility towards a suspension of biological materials (C2C12) showed that the cancerous cells could be successfully controlled and quantified by a statistical analytical method. A UV-visible spectrophotometer was used to record the absorption spectra at $\lambda_{\max }=250$ for the nanomaterials (SiNPs), $\lambda_{\max }=280$ for the biological materials (C2C12) and $\lambda_{\max }=400$ for the SiNPs with C2C12.

\section{Results and discussion}

\section{$\mathrm{X}$-ray diffraction results}

Fig. 1 shows the XRD pattern of the SiNPs. The obtained spectrum demonstrates that all the particles were crystalline in nature, with smaller dimensions ( $20 \pm 2 \mathrm{~nm}$ in size). The diffraction peaks in their spectrum could be directly assigned to pure SiNPs. The obtained spectrum illustrates the phase identification and matches with JCPDS cards no. 39-1346. The peak notations of $28.45\langle 111\rangle, 47.25\langle 220\rangle, 56.10\langle 311\rangle, 68.95\langle 400\rangle$ 


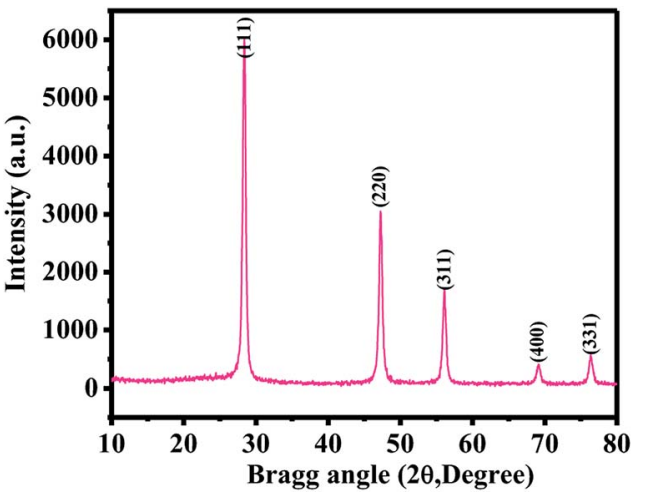

Fig. 1 X-ray diffraction pattern of SiNPs prepared via the microwaveassisted plasma method.

and $76.40\langle 331\rangle$ could be clearly indexed with the silicon phase. The crystallite size of SiNPs was calculated from Scherrer's formula and was found to be $\sim 22 \mathrm{~nm}$. As per the peak positions of the obtained spectrum, it was evident that there was no impurity of other materials present., ${ }^{1,2}$

\section{Morphological assessment (FESEM, TEM and AFM results)}

The structural evaluation of the microwave-assisted SiNPs was analyzed via FESEM and TEM. Fig. 2a and (b) show the magnified images of the SiNPs. Several tiny spherical NPs can
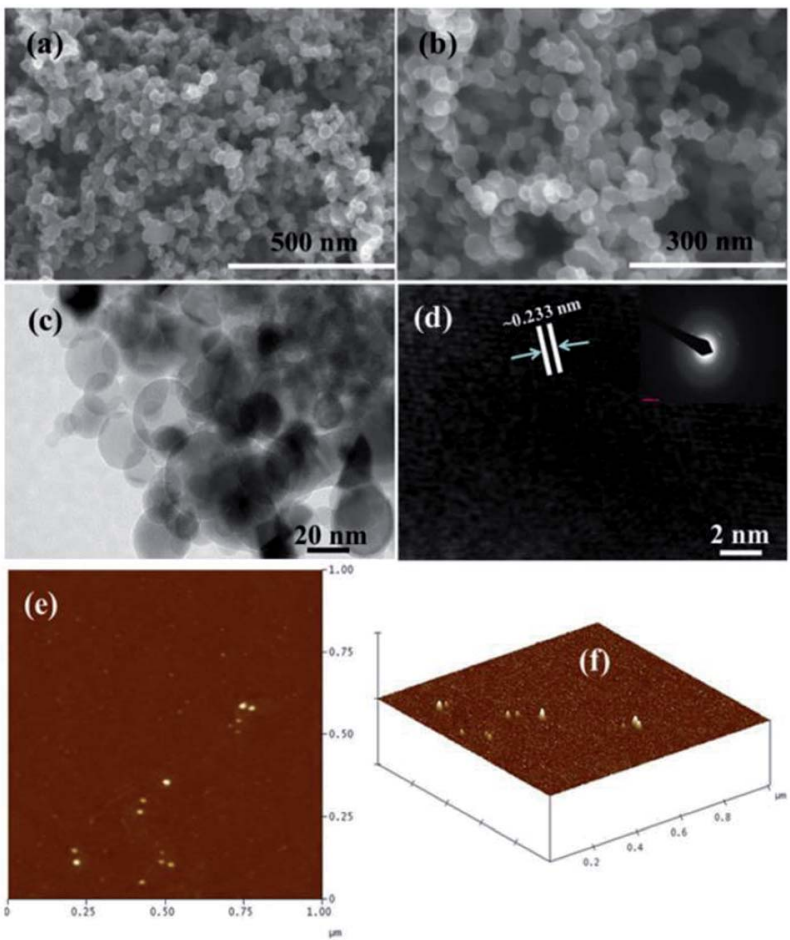

Fig. 2 Spherical-shaped structures in the low (a) and high (b) magnification FESEM images of SiNPs, respectively. TEM (c) and HRTEM (d) images showing the general morphology of the prepared NPs and their fringe distance between two lattices $(\sim 0.233 \mathrm{~nm})$. AFM images of prepared SiNPs. General topographical image (e) and (f) the distance between particles, which is $\sim 20 \mathrm{~nm}$, (horizontal, vertical and surface distances). be seen in the image in an aggregated form (Fig. 2b). Furthermore, the magnified image shows that the average size of each SiNP is about $20 \pm 2 \mathrm{~nm}$. For more details related to the structural elucidation, TEM images were acquired at an accelerating voltage of $200 \mathrm{kV}$. Fig. 2c shows the TEM image of the processed SiNPs alongside a selected area electron diffraction (SAED) image (Fig. 2d). The particles have a spherical morphology and are agglomerated in nature. Due to the collision of particles inside the reaction chamber, soft and hard agglomerated particles can be formed. Additionally, the particles can be aggregated outside the reactor upon oxidation due to the formation of a wrapped oxide shell around the softly agglomerated particles. The selected area electron diffraction pattern (SAED) of SiNPs is shown in the inset of Fig. 2d. The sharp ring from silicon clearly indicates that the particles are crystalline in nature. Fig. 2d shows a high-magnification TEM image of the NPs, demonstrating that the lattice distance (fringes) is $\sim 0.233 \mathrm{~nm}$, and corresponds to the crystalline nature of the pure phase of SiNPs. The average particle diameter $\left(d_{\mathrm{p}}\right)$ is about $20 \pm 22 \mathrm{~nm}$ (Fig. $2 \mathrm{c}$ and d).

The FESEM and TEM data are in accordance and analogous with the XRD data. Each SiNP is fully spherical in shape covered with other particles (Fig. 2c). In addition to these observations, the atomic force microscopy (AFM) data also justified the formation of spherical-shaped SiNPs. Fig. 2(e) shows the AFM surface of NPs and Fig. 2(f) shows a 3D image of the spheres. From the images, we can easily see that each NP is spherical in shape and is about $\sim 20 \mathrm{~nm}$ in size, which is analogous to the FESEM and TEM observations (Fig. 2a-d).

\section{Dynamic light scattering (DLS) and zeta potential}

Dynamic light scattering (DLS) analysis of the microwaveassisted SiNPs was also performed, and the results depicted that the average size of the particulate matter was about $132.6 \mathrm{~nm}$ (Fig. 3a). DLS was used to determine the size of NPs in colloidal suspensions, where the particles have a tendency to collide and form aggregates in an aqueous medium, thus expressing the primary and secondary sizes of the prepared nanostructures. The size of the NPs was found to increase with the collision/interaction of other molecules. Our finding was also in line with previously published literature. ${ }^{60}$ The zeta potential of the SiNPs in an aqueous solution was determined to be $-7.89 \mathrm{mV}$ (Fig. 3b).

\section{FTIR spectroscopy}

Fig. 4 shows the Fourier transformed infrared (FTIR) spectra of SiNPs. The surface of SiNPs is covered with an oxide layer and can be clearly seen by the oxide-related vibration modes on the surface. A broad peak around $1212 \mathrm{~cm}^{-1}$ arises due to $\mathrm{Si}-\mathrm{O}-\mathrm{Si}$ vibrations on the surfaces. ${ }^{61}$ Also, the spectrum contains peaks with sharp intensities at $2268 \mathrm{~cm}^{-1}$ and $874 \mathrm{~cm}^{-1}$, which can be assigned to the $\mathrm{H}-\mathrm{SiO}_{3}$ stretching vibration mode ${ }^{62}$ and $\mathrm{H}-\mathrm{SiO}_{3}$ bending vibration mode,$^{\mathbf{6 1}}$ respectively. In addition to the oxide peaks, a pure hydrogen-terminated silicon surface also prevails at the surface, which is evident by the small intensity stretching vibration mode of $\mathrm{Si}-\mathrm{H} x(x=1-3)$ at $2083 \mathrm{~cm}^{-1} \cdot{ }^{63}$ A very small 

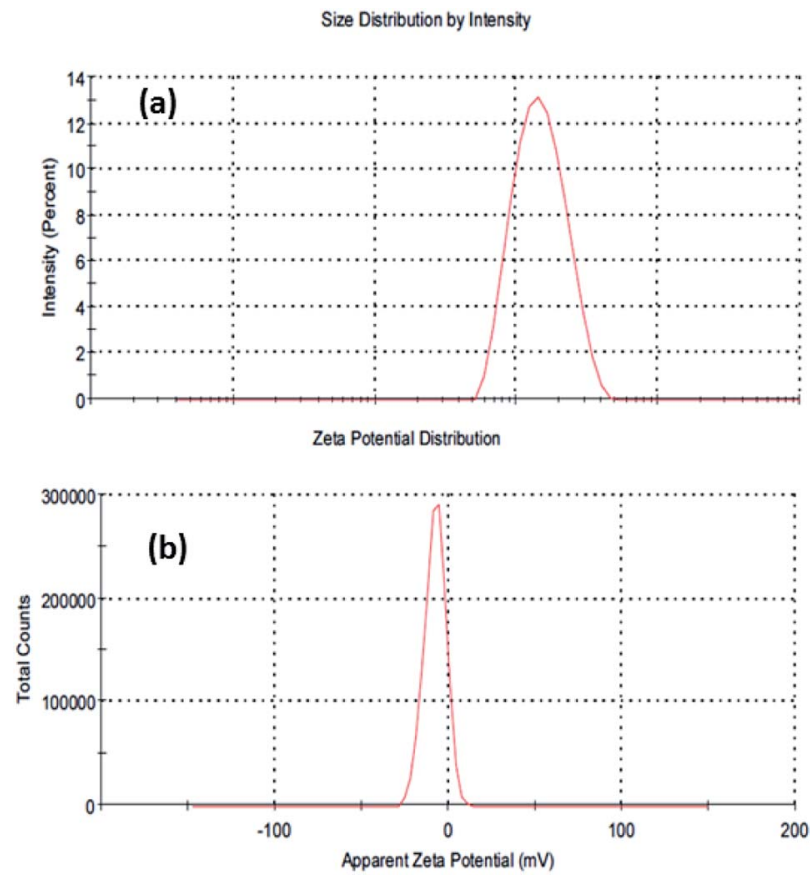

Fig. 3 Dynamic light scattering (DLS) size distribution (a) and zeta potential (b).

signature of $\mathrm{C}-\mathrm{H}$ stretching mode is also seen, which represents the vibration of $\mathrm{C}-\mathrm{CH}_{3}$ signal at $2973 \mathrm{~cm}^{-1}$, while the signals at $2930 \mathrm{~cm}^{-1}$ and $2888 \mathrm{~cm}^{-1}$ denote $\mathrm{C}-\mathrm{CH}_{2}$ stretching. ${ }^{64}$ These vibrations are supposed to originate from air contamination of the sample.

\section{Microscopic/morphological changes of $\mathrm{C2C12}$ and their interaction effects with SiNPs}

A measured concentration of SiNPs $\left(1 \mu \mathrm{g} \mathrm{mL}{ }^{-1}\right)$ was employed in the following test. C2C12 cells were cultured in DMEM medium in a plastic flask $\left(75 \mathrm{~mm}^{2}\right)$ at their optimized confluence (50-70\%). Following this, the cells were again harvested via the treatment of trypsinization. The cells were again treated with microwave-assisted prepared SiNPs at various



Fig. 4 FTIR spectra of microwave-assisted plasma-processed SiNPs. concentrations (200 $\mathrm{ng} \mathrm{mL} \mathrm{m}^{-1}, 1000 \mathrm{ng} \mathrm{mL}^{-1}$ and $2000 \mathrm{ng} \mathrm{mL}^{-1}$ ). Alongside these treated samples, a control that was not treated with SiNPs was also tested to check the differences and was incubated in an incubator at $37{ }^{\circ} \mathrm{C}$ for different time periods (24, 48, and 72 h) (Fig. 5A). No sudden change was observed initially (at low (100 $\mathrm{ng} \mathrm{mL}^{-1}$ ) concentration), whereas as the concentration of SiNPs increased with the incubation period (48 $\mathrm{h}$ ), the cells seemed to mononucleate and start to proliferate at $48 \mathrm{~h}$; then, at $72 \mathrm{~h}$, the cells decayed (Fig. 5A). From the obtained observations, it was clear that the cell viability was dose

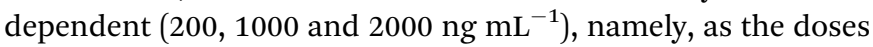
of particles enhanced, the cell viability was affected. ${ }^{56,57}$

\section{MTT assay or cytotoxicity calculations}

The cell viability was assessed with the MTT assay, and the obtained data indicated that the \% of viable and non-viable cells was dose/conc. reliant. The viability at 200, 1000 and $2000 \mathrm{ng}$ $\mathrm{mL}^{-1}$ concentrations were documented as $78 \%, 58 \%$ and $30 \%$, correspondingly, through the MTT data acquired in $24 \mathrm{~h}$. With

\section{(A)}

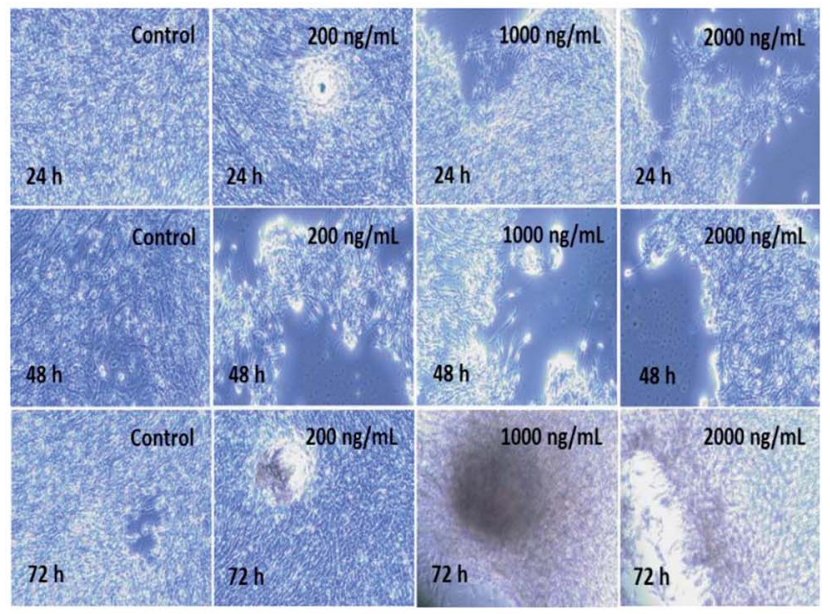

(B)

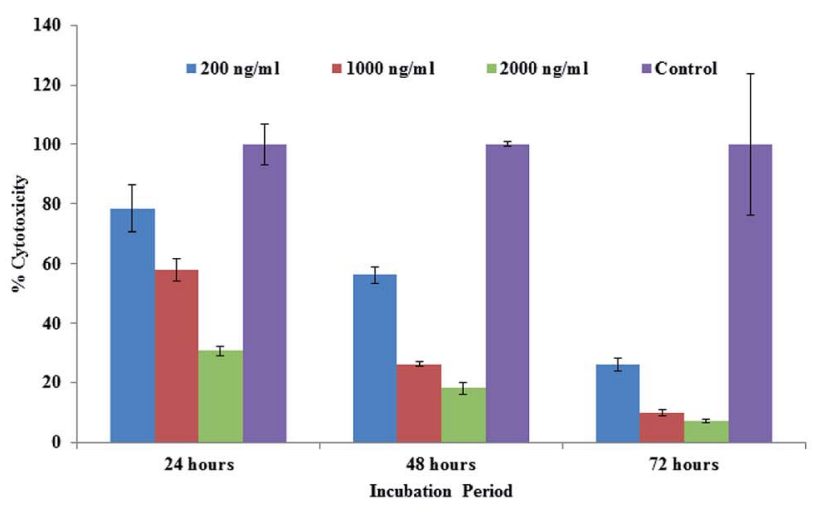

Fig. 5 (A) Microscopic images of the effect on $\mathrm{C} 2 \mathrm{C} 12$ of SiNPs at different concentrations and incubation times. (B) The MTT assay of SiNPs at different concentrations (200 $\mathrm{ng} \mathrm{mL}^{-1}, 1000 \mathrm{ng} \mathrm{mL}^{-1}$ and $2000 \mathrm{ng} \mathrm{mL}^{-1}$ ) and incubation times (24, 48 and $72 \mathrm{~h}$ ) with the control solution. Experiments were performed in triplicate. 
the enhancement in the incubation period, a chronological alternation in cell viability was seen at 200, 1000 and $2000 \mathrm{ng}$ $\mathrm{mL}^{-1}$ concentrations, and the viability was recorded as $56 \%$, $26 \%$ and $18 \%$, separately, by the MTT assay at $48 \mathrm{~h}$. The viability decreased to a single digit percentage after $72 \mathrm{~h}$ incubation, as observed by the concentrations of 200, 1000 and $2000 \mathrm{ng} \mathrm{mL}$ showing viabilities of $26.28 \%, 10.15 \%$ and $7.32 \%$, respectively, by MTT assay (Fig. 5B). The obtained results signify that the microwave-assisted SiNPs reduces cell viability at different doses of NPs in terms of nanogram (ng) (200, 1000 and $2000 \mathrm{ng}$ $\left.\mathrm{mL}^{-1}\right)$ concentration level in different incubation periods $(24$, 48 and $72 \mathrm{~h}$ ). The acquired results also corroborated our previously published work. ${ }^{56,57}$

\section{Effect of SiNPs on caspase 3 and 7 activity}

The cysteine's families of caspases are categorized on the basis of their role and are liable to create either apoptosis or inflammation and are responsible for cell death. ${ }^{65}$ The caspases, which are simply proteases, reduces their peptide bonds and are dependent on the specific aspartic acids. In this process, the aspartic acids/rings, which are involved in the apoptosis, further subdivided as 8, 9, 10 and 12 caspases or are known as effector caspases. ${ }^{65}$ On the other hand, the initiation caspase 3 is also subdivided in to 6 and 7, depending on their location in the cell death pathways. ${ }^{65}$ The initiator caspases (3,6 and 7) are also known as effector's caspases, which are responsible for disorder in the cells when the apoptosis is initiated. The effector caspases have the capability to catalyze the cellular proteins, which is a major cause of cellular death, and also the objectactivated DNase. In case of normal cells, caspase 3 is activated by deoxyribonuclease (CAD) and is suppressed via binding to its inhibitor (ICAD) proteins. The ICAD dissociates in to CAD and can easily enter into the nucleus, which is responsible for the degradation of chromosomal DNA into nucleosomal and is characteristic of apoptosis. ${ }^{\mathbf{6 5 6 6}}$ The monomeric products of DNA degradation (amino acids and nucleotides) are freed in a systematic way, which permits them to be taken up and reused through neighbouring cells. ${ }^{67}$ We analyzed the mRNA level of C2C12 cells in the presence of caspases $3 / 7$ with varied concentrations of SiNPs with control gene (GAPDH) via PCR. The cells were treated with SiNPs at low and high $\left(200 \mathrm{ng} \mathrm{mL} \mathrm{m}^{-1}\right.$ \& $1000 \mathrm{ng} \mathrm{mL} \mathrm{m}^{-1}$ ) concentrations with two different incubation periods ( $24 \& 72 \mathrm{~h}$ ). The acquired results indicated that the caspase 3 and 7 levels of mRNA were significantly altered in cancer cells due to SiNP exposure (Fig. 6A and B, $p<0.05$ for each). In the $24 \mathrm{~h}$ incubation period, the gene expressions of caspase 3 with SiNPs at $200 \mathrm{ng} \mathrm{mL}{ }^{-1}$ and $1000 \mathrm{ng} \mathrm{mL}{ }^{-1}$ were 2.13 and 2.86, respectively. These values changed in the higher incubation period $(72 \mathrm{~h})$ with a concentration of $1000 \mathrm{ng} \mathrm{mL}{ }^{-1}$, namely, by 3.54- and 5.64-fold, respectively, where the gradual change was due to the upregulation of genes (Fig. 6A). ${ }^{56-59}$ The caspases also play an important role in the area of dead or apoptotic cells, presenting as natural ageing in untreated cells.

The change in cells via the genetic expression are interlinked with an untreated (GAPDH for the knockdown observation. It is expected that nanostructured materials would behave as toxic
(A)

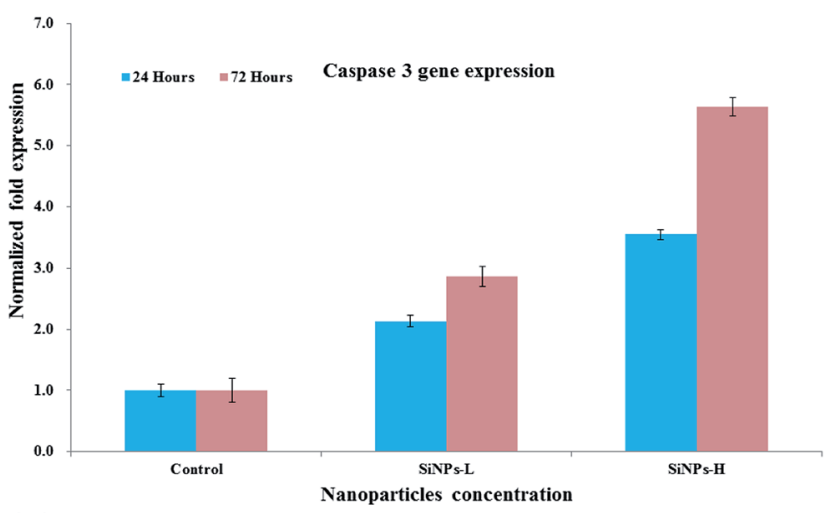

(B)

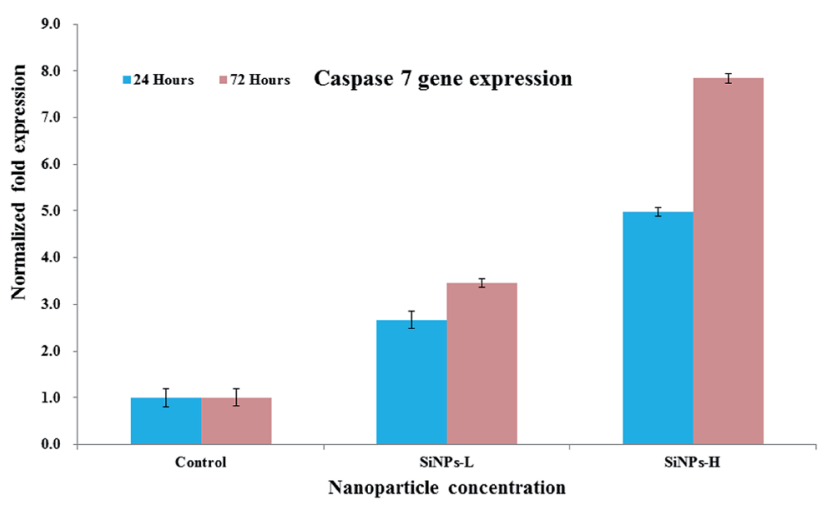

Fig. 6 mRNA expression of C2C12 cells for caspase $3(A)$ and 7 (B) in the presence of GAPDH genes exposed to NPs at low (SiNPs-L (200 ng $\left.\mathrm{mL}^{-1}\right)$ ) and high (SiNPs-H (1000 ng mL $\left.{ }^{-1}\right)$ ) concentrations. Experiments were performed in triplicate.

materials for the growth of cancer cells, as also proved from the obtained results (Fig. 6A and B). At low concentration of the nanostructured materials, the effects were less, whereas as the concentration of NPs increased in the cells, the apoptosis increased, leading to an upregulation in mRNA expression. Similar results were also obtained in the case of caspase 7 when it was incubated for 24 and $72 \mathrm{~h}$ with the prepared NPs. Caspase 7 at a very minute concentration ( $200 \mathrm{ng} \mathrm{mL}{ }^{-1}$ ) of NPs in $24 \mathrm{~h}$ showed a 2.66- and 3.54-fold change in apoptosis, respectively, whereas when a higher concentration $\left(1000 \mathrm{ng} \mathrm{mL}^{-1}\right)$ of SiNPs was introduced with a long incubation period $(72 \mathrm{~h})$, the apoptosis changed by 4.98 - to 7.84 -fold (Fig. 6B). ${ }^{56-59}$

\section{Confocal laser scanning laser microscopy (CLSM) study effect with SiNPs}

Confocal microscopy provides several advantages over normal optical imaging microscopy, such as control of the depth in the field and the ability to acquire several optical sections from specimens. Confocal laser scanning microscopy (CLSM) has been applied recently as it can provide extremely high-quality images in a wet environment as compared to conventional optical microscopy. ${ }^{68}$ The cell images of both control (without NPs) and treated (with NPs) samples were observed through 
CLSM in a $24 \mathrm{~h}$ incubation period, with the cells being stained with PI dye with $5 \% \mathrm{CO}_{2}$. The obtained images illustrate the

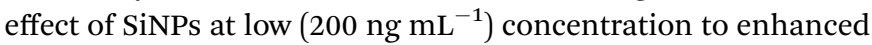
(1000 \& $2000 \mathrm{ng} \mathrm{mL}^{-1}$ ) concentrations (Fig. 7).

The acquired data clarifies that at low concentration, the toxicity of cells with SiNPs was not affected much, whereas when the doses of SiNPs were higher $\left(1000 \& 2000 \mathrm{ng} \mathrm{mL}^{-1}\right)$, the cells were decayed by more than $\sim 85-90 \%$ in total. The obtained data in the form of images was analogous with the quantitative result from the MTT assay (Fig. 5B), which further explains that the cells' toxicity depends on the used concentration of the nanostructured materials, the $\mathrm{pH}$ of the solution, ageing or incubation periods of the cells, etc. ${ }^{56,57}$

\section{Analytical determinations of SiNPs with $\mathrm{C} 2 \mathrm{C} 12$ cells}

The task of analytical methodology was drawing numerical sketch of nanomaterial features specialty and demonstration at perfect level. The analytical consideration provide imperative supervision to select nanomaterial amount (SiNPs) along with passionately against target material C2C12 cells. Eventually, quantify nanomaterial quantity was also defining scope of statistical analytical procedure and followed rules of $\mathrm{ICH}$ guidelines. The International Council for Harmonisation (ICH) guidelines is verify optimization and validated prosperity in terms of statistical parameters. The SiNPs nanomaterial interaction with $\mathrm{C} 2 \mathrm{C} 12$ cells was observed maximum and fixed wavelength $400 \mathrm{~nm}$, without interaction of nanomaterial and C2C12 cells shows absorption spectra at wavelength at 250 and $280 \mathrm{~nm}$ confirmed via UV-visible technique Fig. 8A(i-iii). The concentration of nanomaterials was used to construct a linear calibration graph (where $X$-axis is the concentration and $Y$-axis is the absorbance) (Fig. 8B). The mathematical expression of the significant values for the slope of the regression line, the

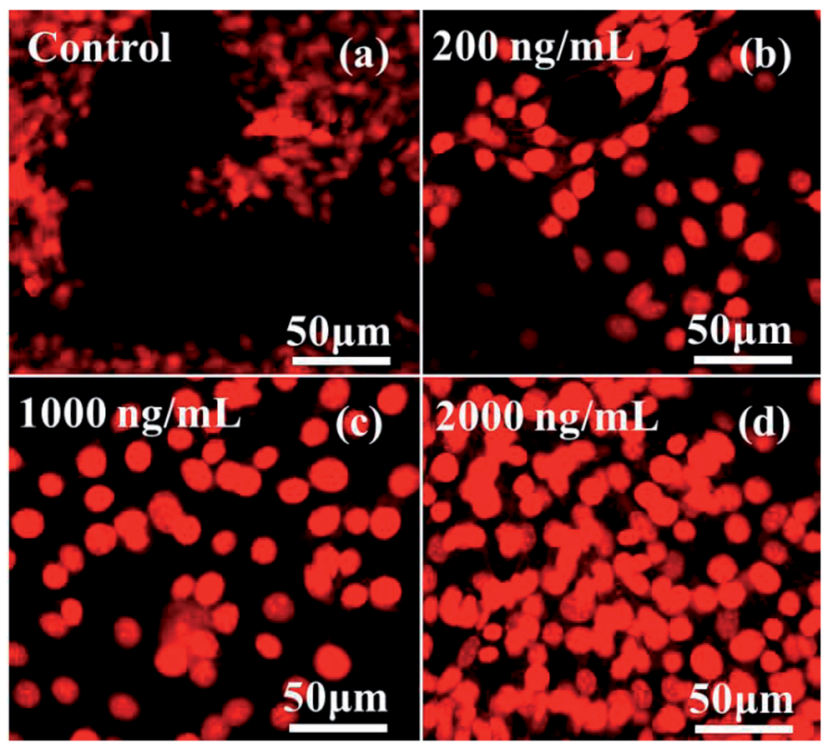

Fig. 7 CLSM images of $\mathrm{C} 2 \mathrm{C} 12$ cells at different concentrations of SiNPs (200 $\mathrm{ng} \mathrm{mL}^{-1}, 1000 \mathrm{ng} \mathrm{mL}^{-1}$ and $2000 \mathrm{ng} \mathrm{mL}^{-1}$ ) at $24 \mathrm{~h} \mathrm{incu-}$ bation period.
(A)

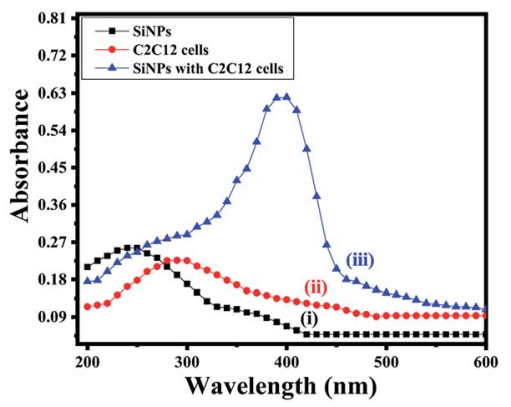

(B)

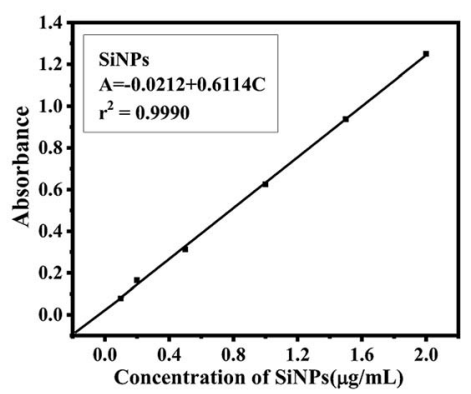

Fig. 8 (A) The absorption spectra of SiNPs (i), C2C12 cells (ii), spectra of SiNPs and $\mathrm{C} 2 \mathrm{C} 12$ cells (iii). (B) The linear calibration graph of SiNPs.

intercept and the correlation coefficient were obtained with the help of the linear regression equation $(A=-0.0212+$ $0.6114 C){ }^{69,70}$ The linear range of SiNPs nanomaterial followed Beer's law and identifies nanomaterial skill, the Beer's law expressions is dependent on the analyzed material (SiNPs). The standard sample concentration for support accuracy in the linear range (conc., $0.1-2.0 \mu \mathrm{g} \mathrm{mL}^{-1}$ ). The statistical parameters for designated assay procedures were used to measure the SiNPs present in the suspension.

The quantitative measurements of the SiNPs and their validation parameters validated the concentration range, identification of the lower detection limit and quantitation limit (LOD \& LOQ), the molar absorptivity, standard deviation, recovery, and slope variance, and showed intermediate precision at high, middle and low levels. ${ }^{70}$ The benefits of statistical parameter analysis and their data's value, successfully established certainty of nanomaterial and indemnity that they are perfect for proposed method. The appropriate and acceptable statistical are summarized in Tables 1 and 2 at the standardized level. The analytical method provides the information of concentration in a chemical compound or solution regulates the quantity of utilized SiNPs nanomaterial. This study provides a clear picture and is helpful for differentiating the nanomaterials (NPs) before and after mixing with the cells (SiNPs C2C12) component. In this experiment, the employed SiNPs and their molecular species absorb the radiation with respect to the suitable wavelength $(\mathrm{nm})$ at maximum absorption $\left(\lambda_{\max }\right)$. The quality of analytes or nanomaterials (SiNPs to control caspase 3 and 7 genes in C2C12 cells) was analyzed via the optimization and validation methods. The statistical technique skill to quantify and provide the relationship between both the nanomaterial/analyte and the biological species which 
Table 1 Statistical parameters for the determination of the SiNPs ${ }^{a}$

\begin{tabular}{lll}
\hline S. no. & Parameters & SiNPs \\
\hline 1 & Colour intensity time & 1 day \\
2 & Temperature of solutions & $25 \pm 1{ }^{\circ} \mathrm{C}$ \\
3 & Wavelength $(\mathrm{nm})$ & 400 \\
4 & Spectra range $(\mathrm{nm})$ & $200-600$ \\
5 & Beer's law limit $\left(\mu \mathrm{g} \mathrm{mL} \mathrm{mb}^{-1}\right)$ & $0.1-2.0 \mu \mathrm{g} \mathrm{mL}^{-1}$ \\
6 & Molar absorptivity $\left(\mathrm{L} \mathrm{mol}^{-1} \mathrm{~cm}^{-1}\right)$ & $6.25 \times 10^{2}$ \\
7 & Linear regression equation & $A=-0.0212+0.6114 C$ \\
8 & $\pm t_{\text {s } a}$ & $5.68 \times 10^{-3}$ \\
9 & $\pm t_{\mathrm{s} b}$ & $5.07 \times 10^{-3}$ \\
10 & Correlation coefficient $(r)$ & 0.9990 \\
11 & Variance (So $\left.{ }^{2}\right)$ of calibration line & $6.890 \times 10^{-3}$ \\
12 & Detection limit $\left(\mu \mathrm{g} \mathrm{mL} \mathrm{mL}^{-1}\right)$ & 0.044 \\
13 & Quantitation limit $\left(\mu \mathrm{gL} \mathrm{m}^{-1}\right)$ & 0.135
\end{tabular}

${ }^{a} \pm t_{\mathrm{s} a}$ and $\pm t_{\mathrm{s} b}$ are the confidence limits for the intercepts and slope, respectively.

differentiates the result data's. Fig. $8 \mathrm{~A}(\mathrm{i}$, ii, iii) shows the obtained UV-visible absorbance of SiNPs at $\lambda_{\max }$ of $250 \mathrm{~nm}$, whereas the C2C12 and SiNPs-C2C12 show the absorbance at $\lambda_{\max }$ of 290 and $400 \mathrm{~nm}$ wavelengths, respectively. From the obtained $\lambda_{\max }$ values of SiNPs, C2C12 and SiNPs-C2C12, a calibration graph was constructed for SiNPs by plotting the absorbance against the concentration (conc., 0.1-2 $\mu \mathrm{g} \mathrm{mL}^{-1}$ ), which gave the linear graph (Fig. 8B) and the evaluated linear regressive equation $(A=-0.0212+0.6114 C)$ of calibration data obtained $(n=6)$ with the help of absorbance verses concentration gives the value of intercept $(a)$, slope $(b)$, and correlation coefficient. ${ }^{69,70}$ The molar absorptivity for NPs (Si NPs $=6.25 \times 10^{2} \mathrm{~L}$ $\mathrm{mol}^{-1} \mathrm{~cm}^{-1}$ ) of the resulting sample solution indicated the sensitivity, detection limit (LOD) and quantitation limit (LOQ) and relative standard deviation (RSD) and shows the system suitability of the proposed method for the lowest concentration level. ${ }^{71}$ The empirical formula provided more reliable values to ensure that they fitted the proposed method and confirmed that this method is accurate, precise, reproducible and gives adequate results. The recovery and relative standard deviation (RSD) experiments are summarized in Table 2. It is evident from both the tables (Tables 1 and 2) that the recoveries (99.44$100.94 \%$ ) were almost accurate and satisfactory. ${ }^{70,71}$

\section{Possible proposed mechanism}

Several basic characterizations were performed for the nanostructural studies of the SiNPs, such as their crystallinity from $\mathrm{XRD}$ and structural studies (FESEM, TEM and AFM). In addition, the chemical functional behavior was obtained from FTIR spectroscopy. The mechanism of toxicity between the nanomaterial and their biological interaction with $\mathrm{C} 2 \mathrm{C} 12$ cells was elucidated. On the basis of the obtained characterizations and the hypothesis, the toxicity of cells depends on various types of parameters, such as the size of the used nanostructures, shape of the material, chemical content and dose/concentration of NPs, and cells concentration. These also affect the endocytic uptake of cells. ${ }^{72-74}$

In our experiments, we observed that the SiNPs had much less density, so the small $(20 \pm 2 \mathrm{~nm})$ spherical nanostructures had the ability to enter easily into the cell membrane because the size of each cell usually goes up to around $\sim 20 \mu \mathrm{m}$, so there is enough space for the nanostructures to enter in the cells. ${ }^{56,57}$ Initially, NPs were attached on the surface/cell membranes of cancer cells. Due to the larger size, they exhibited pores in their cell organization, which provided a way for small SiNPs to enter into the cells and to rupture the layer of the cell walls. At the initial low concentration $\left(200 \mathrm{ng} \mathrm{mL}^{-1}\right)$ of SiNPs, the \% cell death was less, maybe due to the low density of SiNPs and low concentration. At higher doses of SiNPs, such as 1000 and 2000 $\mathrm{ng} \mathrm{mL}^{-1}$, the high density of SiNPs in liquids can strongly favour the rapid formation of adducts. ${ }^{72-74}$ It is assumed that the formed adducts of SiNPs have the ability to destroy the cell organelles, which ultimately leads to cell death.

Various statistical parameters, such as linearity, range, accuracy, precision, repeatability, specificity, LOD and LOQ were studied under the International Conference of Harmonization (ICH) guidelines. ${ }^{69-71}$ The statistical analytical technique plays an important role in promoting the capability of nanomaterials, as demonstrated in terms of the statistical parameters. Frequently parameters are resolve the standard values of straight line slope and intercept coefficient of correlation, molar

Table 2 Test of the precision and accuracy of the proposed method ${ }^{a}$

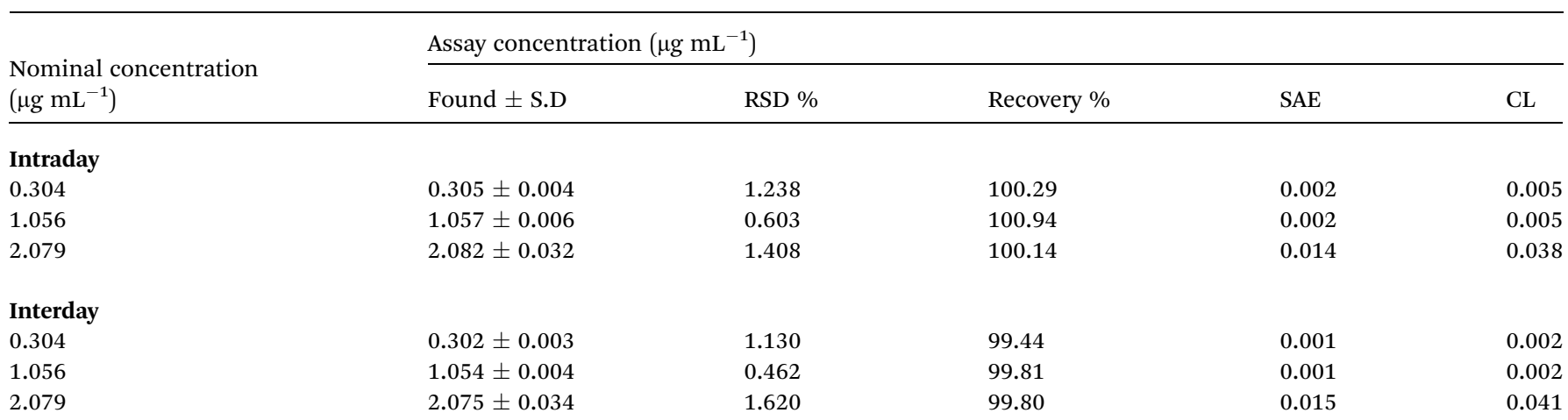

${ }^{a}$ Mean \pm SD for performed over a period $(n)$ of 5 days. Relative standard deviation (RSD), standard analytical error (SAE) and confidence limit (CL) at 95\% confidence level. 
absorptivity, detection and quantitation limit, slope variance and assay precision. The standard performance of statistical parameters was devoted for the suitable quantity of SiNPs in solution, regulate the contaminated material. Therefore, essential prescriptions are involved in minimum concentration to investigation plan for exactingly defined accepted quantity with quality data's to identify the reaction provisions. In this connection, UV-visible technique which has provision to give the absorption spectra for the experimental samples in respect to absorbance, which is trustworthy values of consequential data's, and decided affection/interaction between SiNPs and cancerous cells. The resulting data from the UV-visible spectra show that the concentration of SiNPs is directly proportional to that in the test solutions in the analytical procedure. Beer's law was obeyed in the concentration range from $0.1-2.0 \mu \mathrm{g} \mathrm{mL} \mathrm{L}^{-1}$ and therefore, the selected concentration range was fixed for the SiNPs (Fig. 8a). The linear regressive equation data's are communicate to the skill of regression equation $(A=-0.0212+$ $0.6114 C)$ of number of six degree of freedom $(n=6)$, draw a plot on $x$-axis concentration of SiNPs and $y$-axis absorbance to support the mathematical parameters value in the form of straight line graph. The straight line graph or regression value confined intercept and slope of line, apparent molar absorptivity (SiNPs $\left.=6.25 \times 10^{2} \mathrm{~L} \mathrm{~mol}^{-1} \mathrm{~cm}^{-1}\right)$ slope variance $\left(\mathrm{So}^{2}=\right.$ $\left.6.890 \times 10^{-3}\right)$, correlation coefficient $\left(r^{2}=0.9990\right),\left( \pm t_{\mathrm{s} a}=5.68\right.$ $\times 10^{-3}$ and $\left.\pm t_{\mathrm{s} b}=5.07 \times 10^{-3}\right)$, detection limit $(\mathrm{LOD}=0.044 \mu \mathrm{g}$

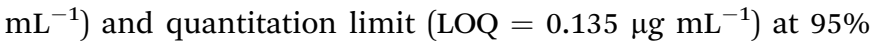
assurance standard, respectively (Table 1). The assay precision was capable with replicate sets of SiNPs (analyte) along with three concentrations, which signified the entire range of standard linear curve (Fig. 8b). The assay intra-day and inter-day precision analysis of SiNPs at three concentration levels $(0.304$, $1.056 \& 2.079 \mu \mathrm{g} \mathrm{mL}{ }^{-1}$ ) were conceded the same day and five uninterrupted days. The assay precision and accuracy demonstrated relative standard deviation (RSD) values for SiNPs that ranged from $0.603-1.238 \%$ and $0.462-1.620 \%$, respectively, and the results are summarized in Table 2 . The \% recoveries were quantitative for SiNPs (99.44-100.94\%), designating a good quality accuracy of the proposed method and adequate recovery values of RSD \%, as investigated by the spectrophotometry technique. Overall result data's are friendly to release SiNPs quantity for manage caspase 3 and 7 in C2C12 cells and their satisfactory values are adequately validated to approval performance of statistical parameters under the guidelines of ICH. Mostly, the amount of SiNPs is responsible for regulated numerous growth of $\mathrm{C} 2 \mathrm{C} 12$ cells. Exclusively, analytical methods are provides selective material information from a wide range concentration of unknown sample and accurateness at assured level. ${ }^{69-71}$

The present approach will enhance step-wise progression in the area of cancer prevention via inexpensive nanomaterials. Several therapies have already been proposed to protect against devastating diseases. However, the full recovery of any therapy for this disease has not yet been found; hence, extensive work still needs to be done to establish a successful therapy for an efficient and effective cure. Nanotechnology is an emerging technology that exhibits its potential to make a great contribution in various areas of science and technology. When utilizing nanomaterials (NMs) such as nanoparticles or quantum dots for biological applications, they can provide better and significant results as compared to the existing technologies. Inorganic nanoscale materials (nanoparticles, quantum dots, etc.) will be commercialized in the near future and will be useful to reduce the growth of cancer cells. The particles will be used in the form of capsules, and will directly and quickly affect cells and proteins as compared to available drugs. Apart from cancer protection, NPs will also be used in near future as an antimicrobial drug. Such inorganic nanomaterials will reduce the cost as compared to the available organic drugs.

\section{Conclusion}

In this work, good quality spherical-shaped silicon nanoparticles were successfully achieved from a microwave-assisted process. The obtained nanostructures were characterized in terms of their physicochemical characteristics, such as crystallinity of the material as examined via XRD, where the assigned peaks and their intensity defined that the material exhibited a good crystalline nature. A morphological study was performed via FESEM and TEM, which again showed that the prepared materials had a good shape and size $(\sim 20 \pm 2 \mathrm{~nm})$. From AFM, the topographical evaluation of the NPs also justified the structural observations. In addition, the DLS and zeta potential were also examined to know the hydrodynamic size of the prepared SiNPs, and the results indicated that the size of the particulate matter in the liquid medium was up to $132.6 \mathrm{~nm}$. The chemical footprint of the material was also analyzed via FTIR spectroscopy, and the results were an agreement with the other analyzed data. The prepared SiNPs were employed to control the growth of cancer cells, i.e., C2C12 cells in a dosedependent manner. To obtain the details of this, the \% of viable and non-viable cells were examined with an MTT assay, which revealed that initially, the cell death was less, whereas when the doses of SiNPs and their incubation period were increased, the cells were completely damaged. The results of the study were also proved via performing confocal microscopy in a wet environment. For more accuracy, a genetic study in the presence of caspases 3 and 7 with GAPDH genes were performed with low and high concentration doses of SiNPs and checked with a RT-PCR study. From this, apoptosis was observed at different levels, which again showed that the SiNPs exhibited the ability to regulate the cancer cell proliferation and showed up in the data as an upregulation in genes. For the authentication and validation of the present study, analytical statistical procedures were applied in terms of the determination of the NP quantity and quality, and related to the reduction of cell viability and control of the growth of cancerous cells. The suitability of NPs and their applied concentration, which is an important parameter, was the right choice to fit for the purpose of cancerous cell inhibition. To evaluate this, the statistical parameters were applied to validate the performance, which showed that the suitability, selectivity, sensitivity, rapidity accuracy and precision were the main advantages of the 
proposed method. The optical regressive parameters illustration data's value from regressive equation, molar absorptivity, limit detection and quantitation, correlation coefficient, assay precision was standardize assurance level at 95\%. The authorize the validity of tentative data's for established anti cancerous effects. The appropriate minute dimension of NPs can affect the proliferation rate of cancer cells and the analytical techniques verify this result. The reputable statistical results to explain accuracy and precision in appropriate manners and analyzed via UV-visible spectroscopy for the silica nanoparticles as well as the cancer cells. The ICH guidelines prefer the analytical procedures to authenticated validation results data's at precise level.

\section{Conflicts of interest}

The authors declare that there are no conflicts of interest.

\section{Acknowledgements}

The authors extend their appreciation to the Deanship of Scientific Research at King Saud University for funding this work through research group no (RG-1440-015).

\section{References}

1 A. Gupta, M. T. Swihart and H. Wiggers, Luminescent Colloidal Dispersion of Silicon Quantum Dots from Micro wave Plasma Synthesis: Exploring the Photo luminescence Behavior Across the Visible Spectrum, Adv. Funct. Mater., 2009, 19, 696-703.

2 A. Gupta and H. Wiggers, Surface chemistry and photo luminescence property of functionalized silicon nano particles, Physica E, 2009, 41, 1010-1014.

3 T. M. Atkins, M. C. Cassidy, M. Lee, S. Ganguly, C. M. Marcus and S. M. Kauzlarich, Synthesis of Long T1 Silicon Nanoparticles for Hyperpolarized 29Si Magnetic Resonance Imaging, ACS Nano, 2013, 7(2), 1609-1617.

4 F. Hua, M. T. Swihart and E. Ruckenstein, Efficient Surface Grafting of Luminescent Silicon Quantum Dots by Photo initiated Hydrosilylation, Langmuir, 2005, 21, 6054-6062.

5 Z. F. Li, M. T. Swihart and E. Ruckenstein, Luminescent Silicon Nanoparticles Capped by Conductive Polyaniline through the Self-Assembly Method, Langmuir, 2004, 20, 1963-1971.

6 T. Ribeiro, S. Raja, A. S. Rodrigues, F. Fernandes, J. P. S. Farin ha and C. Baleizão, High performance NIR fluorescent silica a nanoparticles for bioimaging, RSC Adv., 2013, 3, 91719174.

7 S. Wu, Y. Zhong, Y. Zhou, B. Song, B. Chu, X. Ji, Y. Wu, Y. Su and Y. He, Biomimetic Preparation and Dual-Color Bioimaging of Fluorescent Silicon Nanoparticles, J. Am. Chem. Soc., 2015, 137(46), 14726-14732.

8 L. Yang, Y. Liu, Y. L. Zhong, X. X. Jiang, B. Song, X. Y. Ji, Y. Y. Su, L. S. Liao and Y. He, Fluorescent silicon nanoparticles utilized as stable color converters for white light-emitting diodes, Appl. Phys. Lett., 2015, 106, 173109.
9 E. Tiguntseva, A. Chebykin, A. Ishteev, R. Haroldson, B. Balachandran, E. Ushakova, F. Komissarenko, H. Wang, V. Milichko, A. Tsypkin, D. Zuev, W. Hu, S. Makarov and A. Zak-hidova, Resonant silicon nanoparticles for enhancement of light absorption and photoluminescence from hybrid perovskite films and metasurfaces, Nanoscale, 2017, 9, 12486-12493.

10 F. I. Chowdhury, A. Alnuaimi, N. Atab, M. Nayfeh and A. Nayfeh, Enhanced performance of thin-film amorphous silicon solar cells with a top film of $2.85 \mathrm{~nm}$ silicon nanoparticles, Sol. Energy, 2016, 125, 332-338.

11 B. G. Gribov, K. V. Zinov'ev, O. N. Kalashnik, N. N. Gerasi men ko, D. I. Smirnov, V. N. Sukhanov, N. N. Kononov and S. G. Dorofe ev, Production of Silicon Nanoparticles for Use in Solar Cells, Semiconductor, 2017, 51(13), 1675-1680.

12 P. Wang, S. M. Zakeeruddin, P. Comte, I. Exnar and M. Grät zel, Gelation of Ionic Liquid-Based Electrolytes with Silica Nanoparticles for Quasi-Solid-State Dye-Sensitized Solar Cells, J. Am. Chem. Soc., 2003, 125(5), 1166-1167.

13 H. S. Choi, S. J. Kim, H. W. Choi, C. E. Park, Y. J. Gao, Y. Hang, S. Y. Jeong, J. P. Kim, J. S. Bae and C. R. Cho, Enhanced cycle stability of silicon nanoparticles coated with nitrogen-doped carbon layer for lithium-ion battery anode, Curr. Appl. Phys., 2017, 17(8), 1087-1093.

14 P. Livan, B. Miser, S. Altınok, C. Eyövge, M. K. Aydinol and T. Öztürk, ECS Trans., 2017, 77(11), 373-382.

15 D. Borisova, H. Möhwald and D. G. Shchukin, Mesoporous Silica Nanoparticles for Active Corrosion Protection, ACS Nano, 2011, 5(3), 1939-1946.

16 T. Ribeiro, C. Baleizão and J. P. S. Farinha, Functional Films from Silica/Polymer Nano particles, Materials, 2014, 7, 38813890.

17 R. A. Mitran, D. Berger, C. Munteanu and C. Matei, Evaluation of Different Mesoporous Silica Supports for Energy Storage in Shape-Stabilized Phase Change Materials with Dual Thermal Responses, J. Phys. Chem. C, 2015, 119(27), 15177-15184.

18 D. Tang, W. Zhang, Z. Qiao, Y. Liu and Q. Huo, Functionalized mesoporous silica nano particles as a catalyst to synthesize a luminescent polymer/silica nanocomposite, $R S C A d v$. , 2016, 6, 16461-16466.

19 M. G. Devi and S. Balachandran, A Review on Synthesis, Characterization and Applications of Silica Particles, International Journal of Advanced Engineering and Technology, 2016, 4(7), 249-255.

20 B. Gorji, M. R. A. Ghasri, R. Fazaeli and N. Niksirat, Synthesis and Characterizations of Silica Nanoparticles by a New SolGel Method, J. Appl. Chem. Res., 2012, 6(3), 22-26.

21 R. D. Cakan, M. M. Titirici, M. Antonietti, G. Cui, J. Maier and $\mathrm{Y}$. S. $\mathrm{Hu}$, Hydrothermal carbon spheres containing silicon nano particles: synthesis and lithium storage performance, Chem. Comm., 2008, 3759-3761.

22 M. S. Niasari, J. Javidi and M. Dadkhah, Ball Milling Synthesis of Silica Nanoparticle from Rice Husk Ash for Drug Delivery Application, Comb. Chem. High Throughput Screening, 2013, 16(6), 458-462. 
23 Y. Han, Y. Chen, J. Feng, J. Liu, S. Ma and X. Chen, One-Pot Synthesis of Fluorescent Silicon Nanoparticles for Sensitive and Selective Determination of 2,4,6-Trinitrophenol in Aqueous Solution, Anal. Chem., 2017, 89(5), 3001-3008.

24 Z. Qin, J. Joo, L. Gu and M. J. Sailor, Porous Films: Size Control of Porous Silicon Nanoparticles by Electrochemical Perforation Etching, Part. Part. Syst. Charact., 2014, 31(2), 171.

25 X. Zhang, D. Neiner, S. Wang, A. Y. Louie and S. M. Kauzlarich, A New Solution Route to Hydrogen Terminated Silicon Na Nanoparticles: Synthesis, Functionalization, and Water Stability, Nanotechnology, 2007, 18(9), 095601.

26 F. Venditti, R. Angelico, G. Palazzo, G. Colafemmina, A. Ceg lie and F. Lopez, Preparation of Nanosize Silica in Reverse Micelles: Ethanol Produced during TEOS Hydrolysis Affects the Microemulsion Structure, Langmuir, 2007, 23(20), 10063-10068.

27 K. S. Finnie, J. R. Bartlett, C. J. A. Barbé and L. Kong, Formation of Silica Nanoparticles in Microemulsions, Langmuir, 2007, 23(6), 3017-3024.

28 P. N. R. Kishore and P. Jeevanandam, A novel thermal decomposition approach for the synthesis of silica-iron oxide core-shell nanoparticles, J. Alloys Compd., 2012, 522, 51-62.

29 P. G. Kuzmin, G. A. Shafeev, V. V. Bukin, S. V. Garnov, C. Farcau, R. Carles, B. W. Fontrose, V. Guieu and G. Viau, Silicon Nanoparticles Produced by Femtosecond Laser Ablation in Ethanol: Size Control, Structural Characterization, and Optical Properties, J. Phys. Chem. C, 2010, 114(36), 15266-15273.

30 H. K. Park and K. Y. Park, Control of Particle Morphology and Size in Vapor-Phase Synthesis of Titania, Silica and Alumina Nanoparticles, KONA Powder Part. J., 2015, 32, 85101.

31 A. Bapat, C. Anderson, C. R. Perrey, C. B. Carter, S. A. Camp bell and U. Kortshagen, Plasma synthesis of single-crystal silicon nanoparticles for novel electronic device applications, Plasma Phys. Controlled Fusion, 2004, 46(12B), B97.

32 R. C. Flagan and M. M. Lunden, Particle structure control in nanoparticle synthesis from the vapour phase, Mater. Sci. Eng., A, 1995, 204(1-2), 113-124.

33 M. Moravej, S. E. Babayan, G. R. Nowling, X. Yang and R. F. Hicks, Plasma enhanced chemical vapour deposition of hydrogenated amorphous silicon at atmospheric pressure, Plasma Sources Sci. Technol., 2004, 13, 8-14.

34 J. Zhao, V. Singh, P. Grammatikopoulos, C. Cassidy, K. Ara nishi, M. Sowwan, K. Nordlund and F. Djurabekova, Crystallization of silicon nanoclusters with inert gas temperature control, Phys. Rev. B: Condens. Matter Mater. Phys., 2015, 91, 035419.

35 C. L. Andaluz and S. L. Girshick, Controlled Fluxes of Silicon Nanoparticles to a Substrate in Pulsed Radio-Frequency Argon-Silane Plasmas, Plasma Chem. Plasma Process., 2017, 37, 43-58.
36 P. E. D. Nunzio and S. Martelli, Coagulation and Aggregation Model of Silicon Nanoparticles from Laser Pyrolysis, Aerosol Sci. Technol., 2006, 40, 724-734.

37 S. H. Ng, J. Wang, D. Wexler, S. Y. Chew and H. K. Liu, Amorphous Carbon-Coated Silicon Nanocomposites: A Low-Temperature Synthesis via Spray Pyrolysis and Their Application as High-Capacity Anodes for Lithium-Ion Batteries, J. Phys. Chem. C, 2007, 111, 11131-11138.

38 K. Uchida, K. Higashi, K. Hishida, A. Hotta and N. Miki, Electrospray formation of ring-shaped silica nanoparticles, Jpn. J. Appl. Phys., 2015, 54, 020302.

39 M. Nakamura, M. Shono and K. Ishimura, Synthesis, Characterization, and Biological Applications of Multi fluorescent Silica Nanoparticles, Anal. Chem., 2007, 79(17), 6507-6514.

40 L. L. Li and H. Wang, Enzyme-coated mesoporous silica nano particles as efficient antibacterial agents in vivo, $A d v$. Healthcare Mater., 2013, 2(10), 1351-1360.

41 A. Watermann and J. Brieger, Mesoporous Silica Nanoparticles as Drug Delivery Vehicles in Cancer, Nanomaterials, 2017, 7, 189, DOI: 10.3390/nano7070189.

42 K. Hata, K. Higashisaka, K. Nagano, Y. Mukai, H. Kamada, S. I. Tsunoda, Y. Yoshioka and Y. Tsutsumi, Evaluation of silica nanoparticle binding to major human blood proteins, Nanoscale Res. Lett., 2014, 9, 668.

$43 \mathrm{X}$. Li, J. Zhang and H. Gu, Adsorption and Desorption Behaviors of DNA with Magnetic Mesoporous Silica Nanoparticles, Langmuir, 2011, 27(10), 6099-6106.

44 S. Santra, Fluorescent Silica Nanoparticles for Cancer Imaging, Cancer Nanotechnol., 2010, 624, 151-162.

45 I. Y. Kim, E. Joachim, H. Choi, H. Choi and K. Kim, Toxicity of silica nanoparticles depends on size, dose, and cell type, Nanomedicine, 2015, 11(6), 1407-1416.

46 Y. Wu, W. Tang, P. Wang, C. Liu, Y. Yuan and J. Qian, Cytotoxicity and Cellular Uptake of Amorphous Silica Nanoparticles in Human Cancer Cells, Part. Part. Syst. Charact., 2015, 32(7), 779-787.

47 M. Ahamed, Silica nanoparticles-induced cytotoxicity, oxidative stress and apoptosis in cultured A431 and A 549 cells, Hum. Exp. Toxicol., 2013, 32(2), 186-195.

48 L. Ruizendaal, S. Bhattacharjee, K. Pournazari, M. RossoVasic, L. H. J. deHaan, G. M. Alink, A. T. M. Marcelis and H. Zuil hof, Synthesis and cytotoxicity of silicon nanoparticles with covalently attached organic monolayers, Nanotoxicology, 2009, 3(4), 339-347.

49 A. P. Sviridov, L. A. Osminkina, A. Y. Kharin, M. B. Gongalsky, J. V. Kargina, A. A. Kudryavtsev, Y. I. Bezsudnova, T. S. Pero va, A. Geloen, V. Lysenko and V. Y. Timoshenko, Cytotoxicity control of silicon nanoparticles by biopolymer coating and ultrasound irradiation for cancer theranostic applications, Nanotechnology, 2017, 28, 105102.

50 S. Jambhrunkar, Z. Qu, A. Popat, J. Yang, O. Noonan, L. Aca uan, Y. A. Nor, C. Yu and S. Karmakar, Effect of Surface Functionality of Silica Nanoparticles on Cellular Uptake and Cytotoxicity, Mol. Pharmaceutics, 2014, 11(10), 36423655. 
51 G. Glorani, R. Marin, P. Canton, M. Pinto, G. Conti, G. Fraca Sso and P. Riello, Pegylated silica nanoparticles:cyto toxicity and macrophage uptake, J. Nanopart. Res., 2017, 19, 294.

52 H. Yang, Q. Y. Wu, C. S. Lao, M. Y. Li, Y. Gao, Y. Zheng and B. Shi, Cytotoxicity and DNA damage in mouse macrophages exposed to silica nanoparticles, Genet. Mol. Res., 2016, 15(3), 15039005, DOI: 10.4238/gmr.15039005.

53 A. Yildirim, M. Turkaydin, B. Garipcan and M. Bayindir, Cytotoxicity of multifunctional surfactant containing capped mesoporous silica nanoparticles, $R S C A d v$., 2016, 6, 32060-32069.

54 D. Sahu, G. M. Kannan, M. Tailang and R. Vijayaraghavan, In Vitro Cytotoxicity of Nanoparticles: A Comparison between Particle Size and Cell Type, J. Nanosci., 2016, 2016, 4023852.

55 G. Liu, Q. Li, W. Ni, N. Zhang, X. Zheng, Y. Wang, D. Shao and G. Tai, Cytotoxicity of various types of goldmesoporous silica nanoparticles in human breast cancer cells, Int. J. Nanomed., 2015, 10(1), 6075-6087.

56 R. Wahab, F. Khan, Y. B. Yang, I. H. Hwang, H. S. Shin, J. Ahmad, S. Dwivedi, S. T. Khan, M. A. Siddiqui, Q. Saquib, J. Musar rat, A. A. Al-Khedhairy, Y. K. Mishra and B. A. Ali, Zinc oxide quantum dots: multifunctional candidates for arresting $\mathrm{C} 2 \mathrm{C} 12$ cancer cells and their role towards caspase 3 and 7 genes, RSC Adv., 2016, 6, 2611126120.

57 R. Wahab, S. Dwivedi, F. Khan, Y. K. Mishra, I. H. Hwang, H. S. Shin, J. Musarrat and A. A. Al-Khedhairy, Statistical analysis of gold nanoparticle-induced oxidative stress and apoptosis in myoblast (C2C12) cells, Colloids Surf., B, 2014, 123, 664-672.

58 M. W. Pfaffl, A new mathematical model for relative quantification in real-time RT-PCR, Nucleic Acids Res., 2001, 29(9), e45.

59 T. Nolan, R. E. Hands and S. A. Bustin, Quantification of mRNA using real-time RT-PCR, Nat. Protoc., 2006, 1, 15591582.

60 W. Cui, J. Li, Y. Zhang, H. Rong, W. Lu and L. Jiang, Nanomedicine, 2012, 8(1), 46-53.

61 G. J. Kluth and M. Roya, Oxidation mechanism of the ammonium-fluoride-treated Si (100) surface, J. Appl. Phys., 1996, 80, 5408.

62 D. V. Tsu, G. Lucovsky and B. N. Davidson, Effects of the nearest neighbors and the alloy matrix on $\mathrm{SiH}$ stretching vibrations in the amorphous SiOr: $\mathrm{H}(0<\mathrm{r}<2)$ alloy system, Phys. Rev. B: Condens. Matter Mater. Phys., 1989, 40, 1795.

63 C. M. Denise, A. E. Erik, L. N. Ryan and S. A. Eray, Silicon hydride composition of plasma-deposited hydrogenated amorphous and nano crystalline silicon films and surfaces, J. Vac. Sci. Technol., A, 1998, 16, 3199.

64 M. V. Wolkin, J. Jorne, P. M. Fauchet, G. Allan and C. Delerue, Electronic States and Luminescence in Porous Silicon Quantum Dots: The Role of Oxygen, Phys. Rev. Lett., 1999, 82, 197.

65 M. Enari, H. Sakahira, H. Yokoyama, K. Okawa, A. Iwamatsu and S. Nagata, A caspase-activated DNase that degrades DNA during apoptosis, and its inhibitor ICAD, Nature, 1998, 391, 43-50.

66 H. Sakahira, M. Enari and S. Nagata, Cleavage of CAD inhibitor in CAD activation and DNA degradation during apoptosis, Nature, 1998, 391, 96-99.

67 M. M. Cox, The nonmutagenic repair of broken replication forks via recombination, Mutat. Res., 2002, 510, 107-120.

68 D. A. Peterson, Confocal Microscopy, Encyclopedia of movement Disorders, 2010, https://www.Sciencedirect.com/ topics/neuroscience/confocal-microscopy.

69 R. Wahab and F. Khan, Wet chemically synthesized catalytic nanorods for the deactivation of thymol blue and their statistical analytical applications, Ceram. Int., 2015, 41, 3722-3730.

70 P. Yanez-Sedeno, J. Riu, M. J. Pingarron and F. X. Rius, Electrochemical sensing based on carbon nanotubes, $\operatorname{Tr} A C$, Trends Anal. Chem., 2010, 29(9), 939-953.

71 Q2 (R1) Validation of Analytical Procedures, Text and Methodology, International Conference on Harmonisation, Harmonized Tripartity Guideline, 2005, November, https:// www.ich.org.

72 A. Albanese, P. S. Tang and W. C. W. Chan, The Effect of Nano particle Size, Shape, and Surface Chemistry on Biological Systems, Annu. Rev. Biomed. Eng., 2012, 14, 1-16.

73 E. Fröhlich, The role of surface charge in cellular uptake and cytotoxicity of medical nanoparticles, Int. J. Nanomed., 2012, 7, 5577-5591.

74 I. Slowing, B. G. Trewyn and V. S. Y. Lin, Effect of surface functionalization of MCM-41-type mesoporous silica nanoparticles on the endocytosis by human cancer cells, $J$. Am. Chem. Soc., 2006, 128, 14792-14793. 